\title{
Country Context and University Affiliation: A Comparative Study of Business Incubation in the United States and Brazil
}

\author{
Aruna Chandra ${ }^{* 1}$ and Chia-An Chao ${ }^{1}$
}

\begin{abstract}
This study compared university affiliated and non-university affiliated business incubators in the United States and Brazil in order to assess the impacts of country context and affiliation on incubator funding sources, direct financial assistance to client firms and internal versus external service mix through use of quantitative and qualitative data. Affiliations with external entities can provide life giving resources; however, it may also transfer external shocks to the new venture calling for buffers. Results indicated that incubators in the United States have a higher number of funding sources, are more likely to provide direct financial support, and offer more external services relative to Brazilian incubators; whereas Brazilian incubators are more inclined to connect incubatees to external financial resources but provide services in-house. The study results suggested that incubators in both countries use "bridges" and "buffers" to ameliorate resource deficits driven by environmental exigencies.
\end{abstract}

Keywords: business incubators in Brazil and United States; incubator affiliation; funding; financial support; services

Submitted: $\quad$ March $28^{\text {th }} 2016 /$ Approved: Approved: June $6^{\text {th }} 2016$

\section{Introduction}

Business incubators are relatively new strategic intervention organizational forms that have gained popularity in countries around the world for their potential for nurturing new ventures leading to economic growth (Abetti, 2004; Birch, 1981; Carayannis \& von Zedtwitz, 2005; Smilor \& Gill, 1986). As hub organizations that inhabit a unique organizational space, one key measure of their success is their capacity to link their clients to business partners, sources of funds, and other networks (Totterman \& Sten, 2005). Incubators that are better able to connect with partners and share resources and capabilities in the network are presumably better at providing the types of services with higher added value to their client firms (Black \& Boal, 1994; Brush, Green, Hart, \& Haller, 2001). Several studies have focused on internal networking amongst incubator clients (Soetanto \& Jack, 2013; Uzzi, 1997); however, networking by the incubator has also been identified as a critical part of the incubation process (Hackett \& Dilts, 2004; Scillitoe \& Chakrabarti, 2010). Hansen, Chesbrough, Nohria, and Sull (2000) point out that the primary role of the incubator is to provide a rich array of networking connections to client firms, since these network contacts could serve as potential sources of knowledge and resources. In order to provide clients with relevant network connections, the incubator has to develop its network via affiliations with other organizations. The incubator's network could include a variety of organizations ranging from universities (Mian, 1996; Vedovello \& Godinho, 2003), different levels of government organizations (Phillimore, 1999) and businesses (Bakouros, Mardas, \& Varsakelis, 2002).

This study makes a fine grained distinction between networking and affiliation (tie) viewing the latter as a building block or step in the process of networking, since it is the diversity and density of these ties (Burt, 2002; Granovetter, 1973) that determine the potential of a given network. Incubators seek to develop affiliations leading to networks to link firms under their wing to resource-rich environments in order to usher them through early stage death valleys. They mediate the venture's relationship with the environment, which paradoxically can serve as a source of life-giving resources as well as deadly environmental shocks leading to early mortality. Hence, as an intermediary that seeks to moderate the new ventures relationship with its environment, the incubator serves to both buffer (cocoon) and bridge (connect) the new venture to the environment, driven by internal demands of the clients as well as external contextual contingencies in the environment (Amezcua, Grimes, Bradley, \& Wiklund, 2013).

Business incubators affiliated with university (AU) and not affiliated with university (NAU) in the United States and Brazil was the focus of this study. These two countries were chosen since the United States has a relatively more mature, denser incubation marketspace and Brazil is a relatively younger, yet fast growing incubation market. Previous research on the affiliation patterns of United States and Brazilian incubators has indicated that incubator affiliation-in particular, whether an incubator affiliates with a university-matters to a range of incubator services as well as the incubator's own funding (Chandra, Chao, \& Astolpho, 2014). The paper traces the trajectory of incubation growth and evolution in the two countries along with differences in incubator affiliations as they influence incubator funding patterns, service mix and financial services in order to assess the impact of contextual conditions on this support mechanism for new venture creation. Qualitative and quantitative data were collected on the key dimensions of the study in order to triangulate results.

\section{Why United States and Brazil?}

As business incubators gain ubiquity in various parts of the developed and developing world, incubator models have evolved in

(1) Management, Information Systems, and Business Education Department Scott College of Business, Indiana State University, USA. *Corresponding author: Aruna.Chandrasekaran@indstate.edu 
sophistication, variety and complexity. The services that are offered and the configurations they take vary widely, since they are highly sensitive to local environmental conditions and to the unique entrepreneurial ecosystem in that country (Lalkaka, 2003). While incubators have been in existence in the United States since the 1960's, business incubators in developing countries have really only been in evidence in any significant way in the last decade (Scaramuzzi, 2002). By contrast, the United States has a much longer history of incubation and has served as a model for many countries engaging in this form of intervention to support new venture creation. The United States has the oldest and largest incubation system with approximately 1400 incubators, which has evolved into an incubation ecosystem with a plethora of incubator models ranging from public to private incubators. With over 400 incubators, the Brazilian incubation market is counted as the $4^{\text {th }}$ largest in the world after the United States, Germany and China. This study compared the oldest and largest incubation system with an emerging, yet innovative incubation market. Of particular interest in this study is the concept of incubator affiliation and its impact on service mix and resource access.

The institutional context in a country shapes the environment for incubation, and this holds true for almost any country in the world. Capital scarcity, lack of awareness of the incubator as a support mechanism, lack of private investment and high dependence on government for survival along with the lack of well-developed market for risk capital in the later stages of a new firm's growth were cited as major barriers to growth in Brazil. The world of incubation is not wellknown in Brazil even with nearly 400 incubators in existence and the venture capital market is still in its infancy (ANPROTEC, n.d.). In a similar vein, the Global Entrepreneurship Monitor 2013 Report on Brazil (Da Silva, Furtado, \& Zanini, 2013) indicates that the main obstacles to businesses are capital scarcity and high cost, bureaucratic interference in the form of heavy taxes and regulatory burden, lack of coordinated and easily accessible information on entrepreneurial support systems / programs, and an educational system that does not foster an entrepreneurial spirit. Moreover, Brazilian culture tends to be risk-averse encouraging people to prefer the security of a formal job with a large company over an entrepreneurial career fraught with risk and uncertain outcomes (Da Silva et al., 2013).

\section{Incubator Affiliation}

The incubator's affiliation is a critical factor that affects the incubator's ability to access funding for its set-up and operations by forming effective networks with other entities. Furthermore, the incubator's affiliation may also affect the nature and level of tangible and high value services and support it can provide its incubatee firms, particularly its ability to access or link incubatees to sources of capital. Affiliation, as defined in this study emphasizes formal, strong ties, or direct connection / cooperation between a BI and other BIs and/or a university. This definition builds on the concept of the one-to-one transactional network where value growth is much faster, since each new member brings its own potential set of connections to the entire network, thereby enhancing the value of the entire network (Reed, 2001). Affiliation or forging links to external partners for beneficial exchanges may be viewed as part of a process of building a network, where the incubator serves as a 'hub' connecting and mediating relationships between partners. As Burt (2002) noted, a network consists of both interaction and linkages that are in a constant state of renewal and growth to repair bridge/tie decay. Network renewal and growth is accomplished via the mechanism of adding new ties (i.e., affiliations) and upgrading or dropping old ties (Elfring \& Hulsink, 2007).

Peters, Rice, and Sundararajan (2004) view the incubator's role as 'broker, arguing that its value derives from its role as an intermediary to a much larger set of networks. Affiliation may be viewed as a form of inter-organizational relationship built to connect client firms to new resource pools to ameliorate initial resource deficits (Van de Ven, 1993) for the new venture and to buffer it from competition for resources. In addition, affiliation that creates links to multiple networks ensures greater network stability in terms of resource access by providing some measure of insurance against weaknesses in any one network as well as reducing dependence on any one network (Ramachandran \& Ray, 2006). In addition to serving as a bridge to external resources, the initial resource access enabled by affiliation may serve to buffer the new firm from environmental shocks inherent to a firm's formative period (Amezcua et al., 2013) allowing more time for it to strengthen its resource base to fuel its growth. Hence, incubators may use the affiliation mechanism to both build bridges for resource access and to buffer the new venture from external shocks by reducing their resource dependency, bringing us to the issue of whether the country context mediates the incubator's affiliation strategy in resource seeking and service offering. In the following sections, the broad effects of university affiliation regardless of country context is considered first, followed by country effects of affiliation on service mix and resource access.

\section{University Affiliation}

As nodes for knowledge transfer and diffusion in regional innovation systems, universities serve as hubs that connect actors in the triple helix of government, business and academia (Etzkowitz, 2002). Hence, affiliation with a university affords an incubator access to university resources including university faculty, their cutting edge research, their students, other high-quality employees (Mian, 1996; O'Neal, 2005), and other knowledge-based assets (Rothaermel \& Thursby, 2005). Besides the 'knowledge spillover' effect benefiting new ventures housed in a university incubator (Acs, Audretsch, \& Feldman, 1994; Jaffe, Trajtenberg, \& Henderson, 1993), the incubator benefits from the parent university's hub status as well as its own boundary spanning location at the nexus of linkages between various actors in the triple helix. University business incubators are considered as a separate category of incubator by many (Grandi \& Grimaldi, 2004; Peters et al., 2004) due to these distinguishing features.

Another impact of affiliation on fundraising ability is the locational advantage of certain incubators, in particular, incubators affiliated with universities (AU). These incubators are positioned at a strategic crossroads between various actors which also facilitates the building of the network and subsequent increase in the number of 
ties, as these incubators are better able to tap into proximate resource pools as they get more established over time (Autio \& Klofsten, 1998). The university-industry linkages enable formal and informal interaction between academics and industry facilitating exchanges of innovative ideas and resources from the local environment (Gibb, 2000). As boundary spanning organizations, AU incubators are situated at the nexus of multiple networks by virtue of their affiliations as well as their position as a hub connecting isolated stakeholders. Over time, they are expected to become more adept at accessing and leveraging multiple resources.

While the effect of university affiliation has been the subject of previous studies (Mian, 1996), it is not clear whether the impact of university affiliation holds true in different country contexts. This study seeks to answer this question by pooling responses from university affiliated and non-university affiliated incubators from both countries to assess differences, if any, between the two groups in terms of raising funds from a variety of sources. Also, given their different affiliations, strategic focus, and resource access, AU and NAU (not affiliated with universities) tend to differ in their services to and financial support for their clients (Chandra et al., 2014). However, is this observation valid across national boundaries? In the next section, current research on United States and Brazilian incubator funding patterns, financial services to incubatees, and service mix is examined, along with this study's research questions.

\section{Incubator Funding Patterns and Financial Sponsorship}

BIs around the world are usually funded at inception by a coalition of government agencies, universities, private institutions, research centers, or a mixture of all those. Typically, funding for incubator inception (capital costs) and operations (day-to-day) come from different sources. Incubator startup costs are typically funded by synergistic efforts of the organizations from federal, state and local levels of government, universities and public organizations. (Chandra, He, Fealey, 2007; Chandra \& Fealey, 2009; Scaramuzzi, 2002).

In terms of ongoing operations, BIs typically utilize a combination of the following three types of revenue models:

a. rental income and client fees

b. equity positions in promising clients with the expectation of future income

c. on-going funding from sponsors, i.e., university, federal/state/ local government, private industry, private foundation support (infoDev, 2010; Lalkaka, 2003).

\section{Incubator Funding - United States}

The United States had a diversity of non-profit and for-profit incubation models, along with an attendant diversity of funding sources for these incubators. While many incubators in the United States are government funded, through federal, state and local level sources, county grants and corporate sources added to the range of funding for incubators Chandra \& Fealey, 2009). In addition to rental income and service fees, in a few cases some incubators generated revenue by cashing in on their equity positions in their successful incubatees. Other sources of funds for incubators were federal agencies, such as the United States Department of Commerce, state and local economic development agencies interested in job creation, local banks interested in creating a potential business relationship with incubator clients, the local Chamber of Commerce, and corporate and community foundations (Knopp, 2007).

Several types of formal and informal support were available to incubators in the United States. Formal support included capital funds from the State's legislative allocation for incubator infrastructure, competitive grants from the State to select incubators, matching grants for service support for new ventures and funds that were channeled through the State Economic Development Agency (Knopp, 2007). Informal sources of support included tax incentives in the form of tax credits to businesses investing in incubators, low interest loans to local government agencies to support investment in incubators, and private partnership funding where incubators raised money from a coalition of businesses and banks for operational funds. In addition, some incubators had seed fund programs that invested in new ventures in the early stages (Knopp, 2007).

\section{Incubator Funding - Brazil}

Universities played a pivotal role in the creation of incubators in Brazil (Almeida, 2005). Government agencies at the federal and state levels played an important role in supporting incubators, but appeared to work synergistically with universities and industry associations. A representative example was the CIETEC incubator created in 1998 and housed in the University of Sao Paulo. CIETEC, a technology based incubator center was created as a partnership among the following organizations (Universidade de Sao Paulo, n.d.): the Ministry of Science and Technology; the Science, Technology and Economic DevelopmentSecretary of the State of Sao Paulo; University of Sao Paulo; Nuclear and Energy Research Institute; Institute of Technological Research; and SEBRAE (Brazilian Support Service for Micro and Small Business), along with support from National Council for Scientific and Technological Development (CNPq), Research Support Foundation of the State of Sao Paulo (FAPESP), and Financing Agency for Research and Projects (FINEP).

As stated, Brazilian incubators received support from a broad spectrum of federal agencies, such as FINEP, public-private entities like SEBRAE, strong national incubator associations, such as ANPROTEC (National Association of Incubators and Science Parks) as well as local, state and city governments. FINEP, a division of the Ministry of Science and Technology has a program, the PNI, to support Brazilian national incubation. It is linked to the Ministry of Science and Technology and is instrumental in formulating policy for business incubators (InfoDev Study, 2010). SEBRAE (www.sebrae.com) is a non-profit public-private entity that supported incubator and small business development by a utilizing a mix of funds from government payroll taxes and private sources. Initially, SEBRAE provided infrastructure funding for many incubators in the first round and is now focused more on providing start-up funding and training to new 
ventures. The interaction between government, universities and industry appeared to be synergistic and relatively well-coordinated with incubator industry associations playing a boundary spanning role (Scaramuzzi 2002).

Extant literature on United States and Brazilian incubator funding as well as interviews with incubator managers in both countries suggest some unique funding patterns in each country; however they also share some similarities in the variety and sources of funding. In addition, university affiliated incubators appear to share certain commonalities across countries when compared with non-university affiliated incubators. Hence, the first pair of research questions to be addressed in this study is as follows:

1a. Are US and Brazilian business incubators different in their funding variety and sources?

1b. Are AU and NAU business incubators different in their funding variety and sources?

\section{Incubator Financial Services}

\section{Financial Services - United States}

Incubators in the United States provided a range of financial services to their incubatees, including assistance in securing grants from various government agencies at the federal, state and local levels (Chandra \& Fealey, 2009). During the early growth stage, bank loans were an option for a financially viable business. To secure bank loans, a strong business plan that included credible financial projections was a necessary part of the process. In most cases, United States incubators provided assistance in business plan development. A network of relationships, built by the incubator with banks and other service providers, also helped facilitate access to funding from banks for the venture by providing some added credibility. Angel investors may step in at the early stages to fill the growth capital gap in some cases. In the later stages of the venture's life cycle, the incubator may use the power of its network to connect the venture with venture capitalists. Once the growing venture had reached profitable maturity, it had several exit options such as an IPO or acquisition. Even with fewer gaps in the financing chain in the United States, new venture failure is quite high, partly due to financing gaps in the seed to early stages when the new venture was most vulnerable. Several incubators in the United States had seed funds that invested directly in their incubated firms with the expectation of realizing gains upon the success of the incubated firm. Incubators in the United States seem to have moved past the landlord model to a second generation model of incubation, hence may be more risk tolerant in providing start-up capital to their more promising incubatees with the expectation of a profitable exit. Rose Hulman Ventures, for instance, is set up a separate entity from the Rose Hulman Institute of Technology and operates quite entrepreneurially supporting its operations with grants and investment income.

\section{Financial Services - Brazil}

In the early stages of a new venture's life cycle, bank loans are difficult to secure due to the lack of collateral, high interest rates, and a general distrust of the banking system by Brazilian entrepreneurs. The federal agency, FINEP, provided money for projects done in conjunction with a university or research institute. Since Brazilian law does not allow direct flow of government funds to a company, the money went to the university to finance projects within the company (Chandra \& Fealey, 2009). FINEP addressed the need for financing at various stages of firm growth from inception with a $0 \%$ interest program to stimulate firm growth in early stages. BNDES (Bank for Social Development) which used to support only big companies now has a support program for micro-enterprises. Bank loans were not a feasible alternative for small companies in Brazil, since high interest rates made it difficult for micro enterprises to borrow money. The INOVAR Project led by FINEP was a consortium of local and foreign VC firms for establishing an institutional structure for promoting the capacity and culture of venture capital. The goal was to set up a $\$ 200 \mathrm{mi}-$ llion fund for tech-based ventures, a web site for information and virtual matchmaking, which is a Venture Forum and network to support high potentialentrepreneurs (Lalkaka,2003). In general, there was a mix of state, federal, some private funds / venture capital and some seed money, but there clearly were gaps in the financing chain for seed / early to mid-stage growth capital that needed to be addressed.

Brazilian incubators rarely invested their own money in their client firms, though some incubators were experimenting with this approach, such as moving from a service model where the incubator offered services, infrastructure and management services in return for rental fee to a "partnership" model where the incubator took a financial stake in the firm in lieu of rent and the payoff for the incubator would come in the form of profit sharing However, most Brazilian incubators followed a more conservative model of linking client firms to potential investors (Chandra \& Fealey, 2009).

To understand the impacts of country context and affiliation, the second set of research questions to be addressed in this study is as follows:

2a. Are US or Brazilian business incubators more likely to provide direct financial support to incubatees?

2b. Are AU or NAU business incubators more likely to provide direct financial support to incubatees?

\section{Incubator Service Mix}

Incubators provide a spectrum of services ranging from the tangible to intangible, generally classified into categories such as physical/administrative, in-house consulting/business assistance and networking (Mian, 1996; Peters et al., 2004). Incubator performance and 
success is expected to be influenced by the type of service and manner of delivery, with variation in service type largely dependent on sponsor objectives and incubator type ("Benchmarking of Business Incubators," 2002). The impact of various categories of services on incubatee survival and growth has been studied extensively (Colombo \& Delmastro, 2002; Fang, Tsai, \& Lin, 2010; Rothaermel \& Thursby, 2005). Networking is considered a high-value service in the incubation process (Hackett \& Dilts, 2004) since it enables an incubator to connect its client firms to sources of knowledge or other scarce resources to fill resource gaps that may hinder its survival and growth.

This study classifies services into two categories: internal and external (Chandra et al., 2007). Internal services, offered on the incubator's premises are location specific, whereas external services are associated with linking the incubatee to external organizations. In the newer, second generation models of incubation, enterprise development is no longer heavily dependent on internal, tangible administrative services (Hackett \& Dilts, 2004), as in the older, first generation landlord model of incubation with its emphasis on rental space as well as tangible, administrative services designed to lower incubatee cost of doing business and to lend credibility of a physical location to a young, fledgling venture. External intangible services, such as networking that link the incubatee to new knowledge wells of human capital and to other resource pools in the triple helix, is gaining in importance (Peters et al., 2004).

\section{Services - United States}

The service mix in United States incubators varied with the strategic agenda of the sponsor's motives and the type of incubator model. University-affiliated incubators were focused on technology transfer and commercialization and tended to draw upon the resources and networks of the parent university to assist incubated firms. Since faculty is a rich source of expertise, these incubators tended to emphasize the consulting and networking dimension to a larger extent. In general, incubators in the United States were moving toward a service mix that emphasized higher, value-adding services such as networking, which is now recognized as more valuable in the service continuum of incubators. Hence, incubators are transitioning to greater emphasis on external intangible services conducive to the creation of a positive overall environment for incubation (Hackett \& Dilts, 2004). Moreover, US incubators given their age and level of maturity may have higher resource endowments garnered from a more heterogeneous, relatively more resource munificent environment.

\section{Services - Brazil}

The Brazilian incubator movement is defined by its provision of unique and specialized services to support new businesses by providing an innovative environment for their growth through guidance, consulting, in addition to physical space and operational infrastructure (Universidade de Sao Paulo, n.d.). Particular services provided include traditional services, i.e. physical services, access to university labs and infrastructure, and training courses sponsored by SEBRAE. In general, Brazilian business incubators offer more internal services, such as subsidized office space, secretarial support, training and consulting services. This fits the pattern of a younger incubation market relative to the United States that is moving on the path to a second generation emphasis on higher value services derived from affiliation with other actors.

The third set of research questions to be empirically tested and answered in this study is as follows:

3a. Do US and Brazilian business incubators differ in internal / external services they provide to their incubatees?

3b. Do AU and NAU business incubators differ in internal / external services they provide to their incubatees?

\section{Methods}

Both qualitative and quantitative data collection methods were used in this study of business incubation in the United States and Brazil. In-depth, semi-structured interviews with managers of nine incubators in the United States and managers of six incubators in Brazil were conducted to identify key dimensions of relevance for the study. Each interview lasted around 40 minutes and was digitally recorded and transcribed. Key themes / findings that emerged from the interviews were used to develop quantitative survey instruments, as well as to corroborate findings from the empirical data.

United States business incubators who participated in the survey were identified from the National Business Incubators Association's (NBIA) membership directory. Incubator managers of these incubators were the study's key informants as these individuals were most likely to have knowledge of the strategic focus as well as range/scope of services provided by the incubator. Both general business incubators and university incubators were included for a final sample of 121 general business incubators and 67 university-based incubators. The survey instrument along with a cover letter and a self-addressed, postage-paid return envelope was mailed to the 188 incubator managers. As a reminder, a second survey packet was sent out at a one-month interval. This was followed by three more waves of mailings in a fourmonth period. In addition, phone calls were made by the researchers to stimulate response. In the final count, 84 surveys were returned yielding an overall response rate of 44.6 percent.

The quantitative data collection instrument used in Brazil was a webbased survey in Portuguese. The survey instrument was developed after an extensive literature review and interviews with BI managers and policy makers in key cities in Brazil to specifically understand issues relevant to incubation in Brazil, and to triangulate them with findings from the literature. The authors' prior experience with incubator research in the United States, China and Brazil also informed survey development. The survey instrument was first developed in English, translated into Portuguese and back-translated into English. Researchers, academics, incubator managers, and SEBRAE (Agency for Support of Small Businesses) personnel in Brazil pre-tested the survey and provided feedback, which was incorporated into the revised instrument. The Brazilian survey respondents came from a pool of 63 SEBRAE affiliated incubators in the State of Sao Paulo. 
These BI managers received an email invitation requesting their participation and assuring confidentiality of data, with the incentive of sharing aggregate results in return for survey completion. Subsequent telephone calls and reminder e-mails along with the survey link were sent after two weeks and four weeks to spur responses. The quantitative sample was limited to the state of Sao Paulo, since incubation in this state is quite representative of Brazilian incubation efforts, as well as the fact that the research was funded in part by a Fulbright-FAPESP Science and Technology Grant from the State of Sao Paulo and the United States Fulbright Commission. A total of 49 completed responses to the survey were received yielding a response rate of $77.7 \%$.

Characteristics of United States survey early respondents (the first 20 percent of the business incubators that returned the surveys) were compared to the late respondents (the last 20 percent) to test non-response bias (Dooley \& Lindner, 2003). The independent sample t-test comparing the two groups showed no significant differences in (1) the number of incubatees $(t=.554, d f=32, p=.583)$, (2) the number of employees $(t=1.550, d f=32, p=.131)$, and (3) years in operation $(t$ $=-.150, d f=32, p=.882)$. Similarly, no difference were found between the early and late respondents of the survey conducted in Brazil. The independent sample t-test showed no significant differences between the two groups in (1) the number of incubatees $(t=1.48, d f=18, p=.154)$, (2) the number of employees $(t=-1.25, d f=17, p=.226)$, and (3) years in operation $(t=-1.04, d f=18, p=.313)$. The affiliation status of early and late respondents was also compared and no difference was found.

\section{Key variables}

Key variables examined in this study are as follows.

Affiliation Status. Affiliation refers to an incubator's direct and formal association with an external entity with transactional intent. In this study, incubator managers were asked to respond to questions related to their incubator affiliation with a university and/or with other types of organizations, including foundations, other BI(s), state agencies, and companies.

Funding Sources. Incubators managers were asked to indicate their major sources of funds, by selecting from one or more categories: federal government, state government, local government, university, private institutions, and user fees. Funding sources included regular income (such as user fees) and renewal-based support (such as grants from state and local agencies).

Financial Assistance to Incubatees. Incubator managers were asked to indicate whether the incubator provided any forms of financial assistance for the incubatees, such as arranging, or assisting in obtaining loans or grants.

Incubator Services. The survey included 21 potential services in three categories: 11 physical infrastructure/services, 6 traditional/basic inhouse consulting services, and 4 specialized services offered by external firms. Physical services were tangible services such as receptionist, on-site computer facilities, and access to meeting and research facilities. In-house consulting and external specialized services were intangible services. In-house consulting services-such as technical, accounting, financial, marketing, and general business consultationwere services provided by the incubator personnel. External, specialized services were services that an incubator provided based on its relationship with outside providers by way of referrals for the convenience of the client firms. Examples of specialized services include marketing research, legal advice, and venture capital. A complete list of these services is in the Appendix.

\section{Results}

Demographic Information of United States and Brazilian Business Incubators

At a glance, United States and Brazilian BIs appeared to be rather similar; there was no statistically significant difference in their sizes as measured by the number of incubatee firms and the number of employees those firms employed. On average, a US BI housed 17.7 firms and the firms employed 84 staff members, whereas a Brazilian BI housed 16.2 firms and the average number of firm employees was 66. As shown in Table 1, the F-tests for the two-way ANOVA comparing the country and affiliation major effects on the two incubator size measures were not significant. United States BIs, however, were significantly older than their Brazilian counterparts. The average years in operation of BIs in the United States were 9.5 compared to Brazil's 6.9 years.

Table 1

Business Incubator Size and Age by Country and Affiliation

\begin{tabular}{|c|c|c|c|c|c|c|c|c|c|}
\hline & \multirow{2}{*}{\multicolumn{2}{|c|}{ Number of Incubators }} & \multicolumn{2}{|c|}{ No. of Firms } & \multicolumn{2}{|c|}{ No. of Firm Employees } & \multicolumn{3}{|c|}{ Years in Operation } \\
\hline & & & Mean & $S D$ & Mean & $S D$ & & Mean & $S D$ \\
\hline \multirow[t]{2}{*}{ Brazil } & NAU & 22 & 14.71 & 14.07 & 81.65 & 155.29 & & 5.79 & 3.57 \\
\hline & Total & 49 & 16.15 & 12.64 & 65.91 & 113.42 & & 6.89 & 4.10 \\
\hline United & NAU & 34 & 19.32 & 19.75 & 76.94 & & 83.36 & 9.79 & 9.16 \\
\hline States & Total & 84 & 17.68 & 17.28 & 84.04 & & 91.22 & 9.47 & 7.69 \\
\hline
\end{tabular}




\begin{tabular}{|c|c|c|c|c|c|c|c|c|c|}
\hline \multirow[t]{3}{*}{ Total } & NAU & & 56 & 17.56 & 17.80 & 78.69 & 113.92 & 8.26 & 7.74 \\
\hline & $\mathrm{AU}$ & 77 & & 16.82 & 14.18 & 77.32 & 87.59 & 8.74 & 5.91 \\
\hline & Total & 133 & & 17.13 & 15.73 & 77.90 & 99.21 & 8.54 & 6.72 \\
\hline Country & & & & $F=0.44, p>.05$ & & $F=0.72, p>.05$ & & $\begin{array}{l}F=4.97, p<.05^{\star} \\
\text { Partial } \eta^{2}=.038\end{array}$ & \\
\hline Interaction & & & & $F=0.84, p>.05$ & & $F=1.21, p>.05$ & & $F=1.08, p>.05$ & \\
\hline
\end{tabular}

* Significant at the .05 level

While United States BIs were older than Brazilian BIs, there was no difference in age or size between United States AU (Affiliated with University) and NAU (Not Affiliated with University) BIs. Likewise, Brazilian AU and NAU BIs had similar demographics.

\section{Total Number of Funding Sources}

Incubators rely heavily on public and private funding. To answer the first pair of research questions on possible differences between countries and university affiliations in funding variety, the total number of funding sources incubators received was analyzed. From a list of six possible funding sources-three from the government (federal, state, and local), and the other three from university, private, and user fees-incubator managers indicated the sources from which the incubator received their current funding. Table 2 shows the average number of funding sources United States BIs (AU and NAU combined) received was significantly higher than that of Brazilian BIs. Likewise, AU BIs' (United States and Brazil combined) funding numbers significantly surpassed those of NAU BIs. While the two main effects in the two-way ANOVA-country and affiliation-were significant, the Country ${ }^{\star}$ Affiliation interaction effect was not. To further examine affiliation differences within each country, independent sample $t$-tests were performed, which found no significant difference between United States AU and NAU BIs, but the difference between Brazilian AU and NAU BIs was approaching significance $(\mathrm{p}<.10)$. The study results provided support for the positive effect of university affiliation on obtaining funding from more diverse sources along with difference between United States and Brazil.

Table 2

Business Incubator Funding Variety by Country and Affiliation

\begin{tabular}{|c|c|c|c|c|}
\hline & Affiliation & Mean & SD & t-test comparing AU vs. NAU in each country \\
\hline \multirow[t]{2}{*}{ Brazil } & NAU & 1.32 & 1.09 & \multirow{2}{*}{$\begin{array}{l}\text { Brazil: } \\
t(1,47)=-1.84, p=.07\end{array}$} \\
\hline & $\mathrm{AU}$ & 1.96 & 1.32 & \\
\hline United & NAU & 2.15 & 1.13 & \multirow{3}{*}{$\begin{array}{l}\text { United States: } \\
t(1,82)=-.793, p=.43\end{array}$} \\
\hline \multirow[t]{2}{*}{ States } & $\mathrm{AU}$ & 2.36 & 1.26 & \\
\hline & Total & 2.27 & 1.21 & \\
\hline \multirow{2}{*}{ Total } & $\mathrm{AU}$ & 2.22 & 1.28 & \\
\hline & Total & 2.05 & 1.25 & \\
\hline \multicolumn{5}{|c|}{ 2X2 ANOVA } \\
\hline Country & \multicolumn{4}{|c|}{$F(1,132)=7.76, p<.01^{* *}$, partial $\eta^{2}=.057$} \\
\hline Affiliation & \multicolumn{4}{|c|}{$F(1,132)=3.80, p<.05^{*}$, partial $\eta^{2}=.029$} \\
\hline Interaction & \multicolumn{4}{|c|}{$F(1,132)=0.96, p>.05$, partial $\eta^{2}=.007$} \\
\hline
\end{tabular}

* Significant at the .05 level

** Significant at the .01 level

\section{Sources of Funding}

Further analysis of funding to determine whether country context and affiliation played a role in the specific sources of funds BIs received was conducted using Chi-square tests. As shown in Table 3, significantly higher percentages of United States BIs (AU and NAU combined) received state government and university funding and collected user fees than Brazilian BIs. On the other hand, significantly higher percentage of Brazilian BIs received local government funding.

Differences in funding sources were also noted among AU and NAU incubators (United States and Brazil combined). Not surprisingly, 
significantly higher percentage of AU BIs than NAU BIs received university funding, and higher percentage of AU BIs received state government funding (the difference was approaching significance $(\mathrm{p}<.10)$ ). Another difference approaching significance $(\mathrm{p}<.10)$ was higher percentage of NAU BIs than AU BIs received local government funding.

Further examination of sources of funding for AU and NAU BIs in each country found additional differences. A significantly higher percentage of NAU BIs in the United States received local funding while such difference was not observed between Brazilian AU and NAU BIs, as relatively high percentage of Brazilian BIs in both group received local funding. This highlighted the importance of local government funding to Brazilian BIs. Another pattern from the analysis was the clearly differentiated funding source for United States BIs: university funding for AU BIs and local government funding for NAU BIs.

Table 3

Business Incubator Source of Funding by Affiliation and Country

\begin{tabular}{|c|c|c|c|c|c|c|c|}
\hline $\begin{array}{l}\text { Funding } \\
\text { Source } \\
\text { Federal }\end{array}$ & \multicolumn{2}{|c|}{$\begin{array}{l}\text { AU vs. NAU (\% of BI } \\
\text { Receiving Funding) }\end{array}$} & \multicolumn{2}{|c|}{$\begin{array}{l}\text { Brazil vs. United States (\% of BI } \\
\text { Receiving Funding) }\end{array}$} & \multicolumn{2}{|c|}{$\begin{array}{c}\text { Within Country AU vs. NAU } \\
\text { Comparison }\end{array}$} & \multirow{2}{*}{$\begin{array}{l}\chi 2 \text { test } \\
\chi 2=.046 \\
\mathrm{p}=.83\end{array}$} \\
\hline Federal & NAU & $16 \%$ & Brazil & $8 \%$ & $\begin{array}{l}\text { NAU } \\
\text { AU }\end{array}$ & $\begin{array}{l}9 \% \\
7 \%\end{array}$ & \\
\hline & $\mathrm{AU}$ & $14 \%$ & $\begin{array}{l}\text { United } \\
\text { States }\end{array}$ & $19 \%$ & $\begin{array}{l}\text { NAU } \\
\text { AU }\end{array}$ & $\begin{array}{l}21 \% \\
18 \%\end{array}$ & $\begin{array}{l}\chi 2=.088 \\
\mathrm{p}=.77\end{array}$ \\
\hline & $x^{2}=$. & & $\chi 2=3$. & & & & \\
\hline \multirow[t]{3}{*}{ State } & NAU & $21 \%$ & Brazil & $12 \%$ & $\begin{array}{l}\text { NAU } \\
\text { AU }\end{array}$ & $\begin{array}{l}5 \% \\
19 \%\end{array}$ & $\begin{array}{l}\chi^{2}=2.2 \\
\mathrm{p}=.138\end{array}$ \\
\hline & $\mathrm{AU}$ & $35 \%$ & $\begin{array}{l}\text { United } \\
\text { States }\end{array}$ & $39 \%$ & $\begin{array}{l}\text { NAU } \\
\text { AU }\end{array}$ & $\begin{array}{l}32 \% \\
44 \%\end{array}$ & $\begin{array}{l}\chi 2=1.15 \\
\mathrm{p}=.283\end{array}$ \\
\hline & $\chi^{2}=2$ & & $\chi 2=10$ & $=.001 \bullet$ & & & \\
\hline \multirow[t]{3}{*}{ Local } & NAU & $52 \%$ & Brazil & $63 \%$ & $\begin{array}{l}\text { NAU } \\
\text { AU }\end{array}$ & $\begin{array}{l}59 \% \\
67 \%\end{array}$ & $\begin{array}{l}\chi 2=.299 \\
\mathrm{p}=.59\end{array}$ \\
\hline & $\mathrm{AU}$ & $36 \%$ & $\begin{array}{l}\text { United } \\
\text { States }\end{array}$ & $31 \%$ & $\begin{array}{l}\text { NAU } \\
\text { AU }\end{array}$ & $\begin{array}{l}47 \% \\
20 \%\end{array}$ & $\begin{array}{l}\chi^{2}=6.93 \\
p=.008^{* *}\end{array}$ \\
\hline & $x^{2}=3$ & .07 & $\chi 2=13$ & $=.00 * \bullet$ & & & \\
\hline \multirow[t]{3}{*}{ University } & NAU & $5 \%$ & Brazil & $10 \%$ & $\begin{array}{l}\text { NAU } \\
\text { AU }\end{array}$ & $\begin{array}{l}0 \% \\
19 \%\end{array}$ & $\begin{array}{l}\chi 2=4.54 \\
p=.033^{*}\end{array}$ \\
\hline & $\mathrm{AU}$ & $44 \%$ & $\begin{array}{l}\text { United } \\
\text { States }\end{array}$ & $38 \%$ & $\begin{array}{l}\text { NAU } \\
\mathrm{AU}\end{array}$ & $\begin{array}{l}9 \% \\
58 \%\end{array}$ & $\begin{array}{l}\chi 2=20.75, p= \\
000 * \bullet\end{array}$ \\
\hline & $x^{2}=2$ & $00^{* \bullet}$ & $\chi 2=11$ & $=.001 *$ & & & \\
\hline \multirow[t]{3}{*}{ Private } & NAU & $36 \%$ & Brazil & $37 \%$ & $\begin{array}{l}\text { NAU } \\
\text { AU }\end{array}$ & $\begin{array}{l}32 \% \\
41 \%\end{array}$ & $\begin{array}{l}\chi 2=.415 \\
\mathrm{p}=.519\end{array}$ \\
\hline & $\mathrm{AU}$ & $43 \%$ & $\begin{array}{l}\text { United } \\
\text { States }\end{array}$ & $42 \%$ & $\begin{array}{l}\text { NAU } \\
\text { AU }\end{array}$ & $\begin{array}{l}38 \% \\
44 \%\end{array}$ & $\begin{array}{l}\chi^{2}=.277 \\
\mathrm{p}=.59\end{array}$ \\
\hline & $\chi^{2}=$. & & $\chi 2=.3$ & & & & \\
\hline \multirow[t]{3}{*}{ User Fees } & NAU & $52 \%$ & Brazil & $37 \%$ & $\begin{array}{l}\text { NAU } \\
\text { AU }\end{array}$ & $\begin{array}{l}27 \% \\
44 \%\end{array}$ & $\begin{array}{l}\chi^{2}=1.54 \\
\mathrm{p}=.215\end{array}$ \\
\hline & $\mathrm{AU}$ & $49 \%$ & $\begin{array}{l}\text { United } \\
\text { States }\end{array}$ & $58 \%$ & $\begin{array}{l}\text { NAU } \\
\text { AU }\end{array}$ & $\begin{array}{l}68 \% \\
52 \%\end{array}$ & $\begin{array}{l}\chi 2=2.039, p= \\
.153\end{array}$ \\
\hline & $x^{2}=$. & .78 & $\chi^{2}=5$. & $.016^{*}$ & & & \\
\hline
\end{tabular}

* Significant at the .05 level

** Significant at the .01 level

\section{Direct Financial Support to Incubatees}

The second set of research questions focused on direct financial support (loans or any other form(s) of financial assistance) to incubatees from the incubators and possible differences between the countries and between AU and NAU BIs. As shown in Table 4, the results of the Chi-square analysis showed a higher percentage of United States BIs offered direct financial assistance to their firms than Brazilian BIs $(23 \%$ vs. $10 \%)$, and the test was approaching significant $(\mathrm{p}<.10)$. From the perspective of affiliation, higher percentage of NAU offered direct financial support than $\mathrm{AU}$ (26\% vs. $13 \%)$, and the Chi-square test was approaching significance $(\mathrm{p}<.10)$.

\section{Table 4}

Business Incubator Financial Support to Incubatees by Country and Affiliation

\begin{tabular}{|c|c|c|c|c|c|c|}
\hline \multicolumn{2}{|c|}{$\begin{array}{l}\text { AU vs. NAU (\% of BI } \\
\text { Provided Funding) }\end{array}$} & \multicolumn{2}{|c|}{$\begin{array}{c}\text { Brazil vs. United States } \\
\text { (\% of BI Provided } \\
\text { Funding) } \\
\end{array}$} & \multicolumn{2}{|c|}{$\begin{array}{l}\text { Within Country AU vs. NAU } \\
\text { Comparison }\end{array}$} & \multirow{2}{*}{$\begin{array}{l}\chi^{2} \text { test } \\
\chi^{2}=.054 \\
\mathrm{p}=.82\end{array}$} \\
\hline NAU & $26 \%$ & Brazil & $10 \%$ & $\begin{array}{l}\text { NAU } \\
\text { AU }\end{array}$ & $\begin{array}{l}9 \% \\
11 \%\end{array}$ & \\
\hline $\mathrm{AU}$ & $13 \%$ & $\begin{array}{l}\text { United } \\
\text { States }\end{array}$ & $23 \%$ & $\begin{array}{l}\text { NAU } \\
\text { AU }\end{array}$ & $\begin{array}{l}36 \% \\
14 \%\end{array}$ & $\begin{array}{l}\chi^{2}=5.63 \\
\mathrm{p}=.018^{*}\end{array}$ \\
\hline \multicolumn{2}{|c|}{$\chi^{2}=3.35, p=.067$} & \multicolumn{5}{|c|}{$\chi^{2}=3.34, p=.068$} \\
\hline
\end{tabular}

* Significant at the .05 level

** Significant at the .01 level

ISSN: 0718-2724. (http://jotmi.org) 
Delving deeper into the country and affiliation factors, significantly higher percentage of NAU BIs than AU BIs in the United States offered loans / other financial assistance to incubatees. On the other hand, very few Brazilian BIs offered direct financial assistance to incubatees (only five among all 49 Brazilian BIs surveyed did), and there was no significant difference between Brazilian AU and NAU. The statistical analyses provided some evidence of United States over Brazil and NAU over AU in the likelihood of direct financial assistance to tenants, and the evidence was the strongest within the United States between NAU and AU.

\section{Services to Incubatees}

The third pair of research questions asked: Do BIs in different countries and of different affiliation differ in their services to incubatees? In the survey instruments, services were grouped into three categories: physical infrastructure; basic, in-housing consulting services; and specialized/external services. Under each service, incubator managers were asked to indicate whether each service was (1) offered by the incubator or an external provider on-site and the cost of the service included in rent; (2) offered by the incubator or an external

\section{Table 5}

Business Incubator Services to Incubatees by Country and Affiliation provider on-site but required extra payment; (3) offered off-site by an external service provider with payment directly to the provider; or (4) not offered. Different weights were assigned for each of these four levels of services: an on-site service included in the rent received 3 points; an on-site service requiring extra payment received 2 points; an off-site service requiring additional cost received 1 point; and a service not offered received no points. Points under each service category were then averaged to provide an overall indicator of the number and level of service offered by each incubator. This was used as a measure of service intensity.

As shown in Table 5, the country main effect in the two-way MANOVA was significant, while the affiliation main effect was approaching significance $(\mathrm{p}<.10)$, indicating significant effect of the country context and university affiliation on incubator services. Further analysis of between-subject effects found that Brazilian BIs (AU and NAU combined) offered more and higher level of basic, internal services than United States BIs, whereas AU BIs (Brazil and United States combined) offered more and higher level of specialized, external services than NAU. There was no significant different between the countries and affiliation in physical infrastructure.

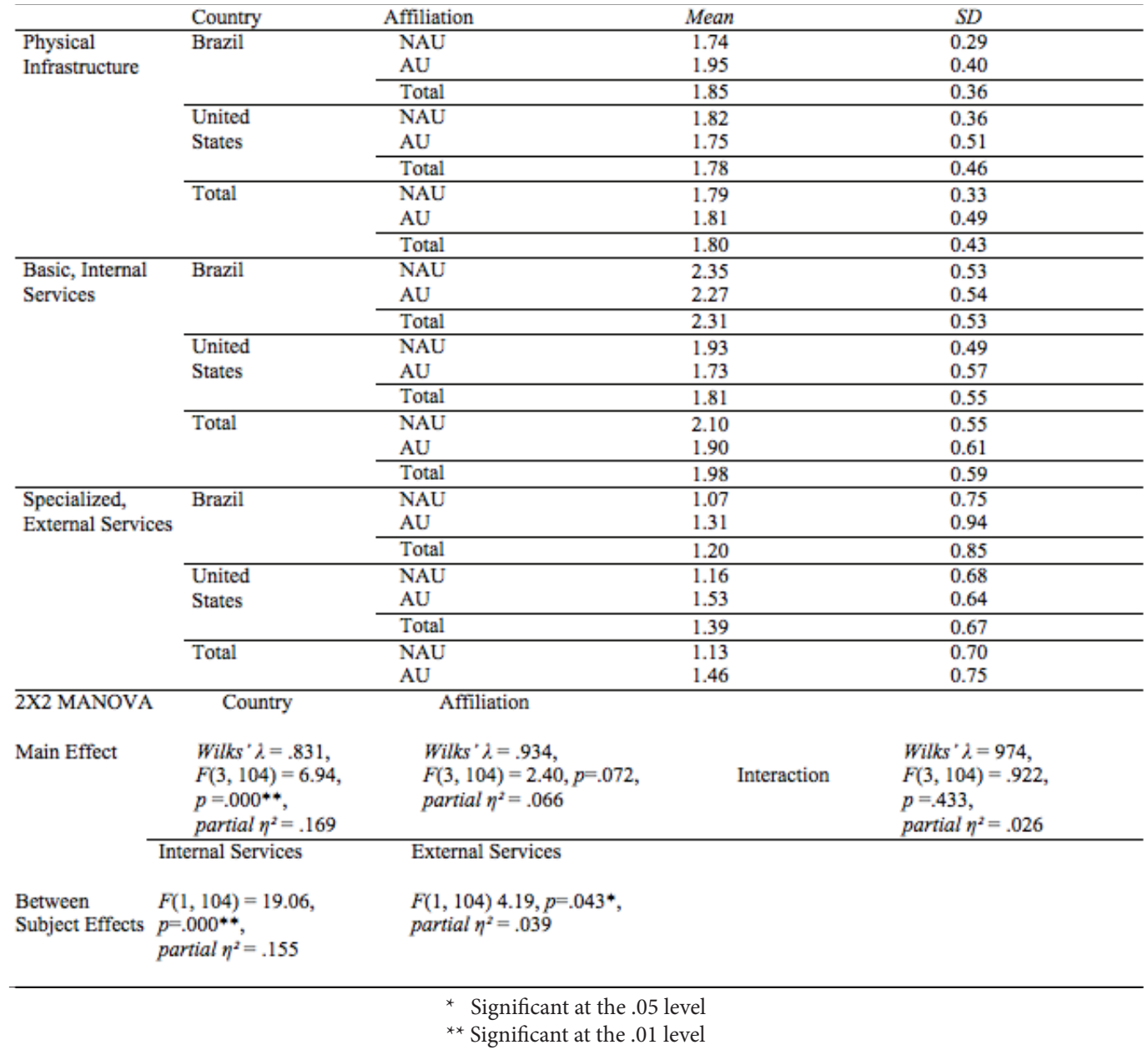


To determine whether AU and NAU BIs in each country differed in their services, separate MANOVA tests were performed. No statistically significant differences were found between AU and NAU BIs in Brazil (Wilks' $\lambda=850, F(1,36)=1.99, p=.13$, partial $\left.\eta^{2}=.150\right)$ and between AU and NAU BIs in in the United States (Wilks' $\lambda=912, F(1$, $68)=2.13, p=.10$, partial $\eta^{2}=.088$ ). Also, the between subject effects comparing the three categories of services in Brazil showed no difference, indicating Brazilian AU and NAU BIs offered similar number and level of services in all three categories; whereas United States AU BIs offered significantly higher number and level of specialized, external services $\left(F(1,68)=5.21, p=.026^{*}\right.$, partial $\left.\eta^{2}=.071\right)$.

\section{Discussion}

This study compared the impact of university affiliation and country context on incubator funding variety and sources of funds, direct financial assistance to incubatees, and service mix of the incubator in terms of internal and external services. University affiliated incubators are considered a separate category of incubators across the world that share certain similarities by virtue of their public sponsorship as well as boundary spanning location at the nexus of the triple helix of government, industry and academia (Etzkowitz, 2002). Hence, the study classified incubators into two broad groups-university versus non-university affiliated-and drew comparisons between the two groups while also considering the influence of country context.

The first research question sought to assess the effect of university and country affiliation on incubator funding variety and source, since an incubator's sources of funds along with its variety largely determine its strategic direction (von Zedtwitz, 2003). Findings indicated that university affiliation does in fact have positive effect on the number of funding sources available to the incubator relative to the non-university affiliated incubator. Unsurprisingly, significantly more university affiliated incubators get funding from their parent universities. Of note was the fact that in addition to university funding, AU incubators also secured more funding from the State compared to the non-university affiliated incubators, who as a group seemed to get more local funding. The greater availability of State funding to AU in general could be explained by the fact that many universities are State funded across countries and hence have a stronger link to State governments compared to their NAU counterparts, who are more rooted in their local contexts with an emphasis on creating local jobs.

The incubator funding picture seemed to undergo a change when differences between the AU and NAU groups were examined within a specific country context. Results indicated that a greater number of United States business incubators received funding from State, university and user fees relative to Brazilian incubators that were predominantly reliant upon local funding. This finding could be explained by the fact that incubators in the United States could have enhanced abilities to tap into a range of funding sources, regardless of affiliation.

Another explanation could be that the United States has a greater diversity of funding sources and a more mature venture capital market relative to Brazil.
The second research question examined differences between the two countries and general impact of university affiliation on direct financial support provided by the incubator to their client firms. Results seem to hint at a pattern where non-university affiliated incubators were more likely to provide direct financial assistance to their start-up firms, with the Chi-square tests approaching significance. However, a clearer picture emerged when comparing university versus non-university affiliated incubators within each country, with more NAU in the United States providing direct financial assistance to their clients. Brazilian incubators (AU and NAU) tended to abstain from providing this form of risk capital to their client firms. This finding may be explained by the fact that in the United States, universities are predominantly publicly funded entities that do not or cannot use monies from the public purse to invest in risky start-ups, no matter how promising, whereas the non-university affiliated incubators do not face similar constraints. As for Brazil, a risk-averse culture and the availability of funds from the other sources, typically governmental seed funds may explain this finding. However, it is notable that in the Brazilian context, both $\mathrm{AU}$ and NAU incubators receive funding from local government with the objective of stimulating the local economy, yet they do not invest some of these funds into the startups. Again, government funds typically come with strings attached, and incubators may not be allowed to invest in risky startups with no track record or collateral to secure the loan.

The third research question examined differences between countries and university affiliation on service mix. Overall, there were no notable differences between AU and NAU in terms of physical and internal services; however, the AU group provided a higher level of external, specialized services. Country context seemed to play a role in the provision of internal versus external services: Brazilian incubators provided a higher level of basic, internal services in house, while United States incubators tended to link incubatees to external service providers. Myriad rules and regulations involved in starting a business may be one reason why Brazilian incubators provide more internal services. Many Brazilian entrepreneurs opted to remain in the informal economy due to bureaucratic barriers, since incorporating a new business requires 15 procedures, three times more than in the United States. New companies had to register with the appropriate government agency, apply for licenses and permits from several state and federal departments, such as environment and labor, register for taxes at multiple levels of government and provide evidence of membership in relevant trade organizations, all of which can easily take more than 5 months. Similarly, a recent survey of Brazil in The Economist points out that, the average firm in Brazil takes 2600 hours to process its taxes and opening a business requires 17 procedures and 152 days, putting Brazil in the 115th place in the ease of doing business in a league of 175 countries ("Special Report on Brazil," 2013).

Considering all findings, the advantage of university affiliation in fund raising, while observed in both countries, is more pronounced in Brazil, possibly due to the fact that universities and faculty have played a vital role in the origin and growth of incubators in Brazil (Etzkowitz, 2002). University affiliation also affects whether or not the 
incubator offers direct financial support to client firms, as NAU are more likely to do so than AU. Universities around the world are typically publicly funded entities, and this finding could be explained by the fact that monies from the public purse are typically not invested in risky ventures, however promising.

As intermediaries that moderate the impact of the environment on new ventures and mediate their connection to the outside world, incubators employ both buffering and bridging strategies (Amezcua et al., 2013). One contribution of this study is that it demonstrates the impact of country context on incubator strategic decisions to offer financial support and internal or external services to client firms and attendant strategies to use bridges or buffers to suit environmental contingencies. Bridges created via affiliations enable resource munificence, while the harsh environmental shocks requires the incubator to develop mechanisms to create protective internal buffers for their young, vulnerable ventures. It is noteworthy that in the United States, over a third of NAU incubators provided direct financial support compared to just nine percent of NAU incubators in Brazil. Brazilian incubators unaffiliated to universities tended to prefer to link their clients to external sources of funds, perhaps due to a dearth of risk capital. This strategy of reaching out to external sources of funding could be an example of the incubator using its affiliations to ameliorate its internal resource deficits. However, the same Brazilian incubators seem to prefer to provide services in house, perhaps as a way of buffering client firms from external forces. This suggests that incubators in Brazil use both bridging and buffering approaches as determined by contextual needs. By contrast, incubators in the United States offer more services externally, but are also more likely to provide direct financial support to client firms suggesting that they too use bridging and buffering to suit environmental exigencies. The adaptive response of incubators to their environment in their strategic choices and service provision is clearly evidenced in this study, which serves as a foundation for future cross-country comparative studies.

\section{References}

Abetti, P. A. (2004). Government-supported incubators in the Helsinki region, Finland: Infrastructure, results, and best practices. Journal of Technology Transfer, 29(1), 19-40.

Acs, Z.J., Audretsch, D.B., \& Feldman, M. (1994). R\&D spillovers and recipient firm size. The Review of Economics and Statistics, 76(2), 336-340.

Almeida, M. (2005). The evolution of the incubator movement in Brazil. International Journal of Technology and Globalisation, 1(2), 258-277.

Amezcua, A. S., Grimes, M. G., Bradley, S. W., \& Wiklund, J. (2013). Organizational sponsorship and founding environments: a contingency view on the survival of business-incubated firms, 1994-2007. Academy of Management Journal, 56(6), 1628-1654. doi:10.5465/ amj.2011.0652
ANPROTEC. (n.d.). Inovadores, A. N. d. E. P. d. E. Retrieved from http://anprotec.org.br/site/menu/incubadoras-e-parques/

Autio, E., \& Klofsten, M. (1998). A comparative study of two European business incubators. Journal of Small Business Management, 36(1), 30-43.

Bakouros, Y. L., Mardas, D. C., \& Varsakelis, N. C. (2002). Science park, a high tech fantasy?: An analysis of the science parks of Greece. Technovation, 22, 123-128. doi:10.1016/S0166-4972(00)00087-0

Benchmarking of Business Incubators. Final Report to the European Commission Enterprise Directorate-Generale. (2002). European Commission Directorate-Generale. Brussels, Belgium. Retrieved from ec.europa.eu/DocsRoom/documents/2767/attachments/1/.../pdf

Birch, D. L. (1981). Who creates jobs? Public Interest, 65, 3-14.

Black, J. A., \& Boal, K. B. (1994). Strategic resources: Traits, configurations and paths to sustainable competitive advantage. Strategic Management Journal, 15, 131-148.

Brush, C. G., Green, P. G., Hart, M. M., \& Haller, H. S. (2001). From initial idea to unique advantage: The entrepreneurial challenge of constructing a resource base. The Academy of Management Executive, 15(1), 64-80.

Burt, R. S. (2002). Bridge decay. Social Networks, 24, 333-363. doi:10.1016/S0378-8733(02)00017-5

Carayannis, E. G., \& von Zedtwitz, M. (2005). Architecting gloCal (global-local), real-virtual incubator networks (G-RVINs) as catalysts and accelerators of entrepreneurship in transitioning and developing economies: Lessons learned and best practices from current development and business incubation practices. Technovation, 25, 95-110. doi:10.1016/S0166-4972(03)00072-5

Chandra, A., Chao, C.-A., \& Astolpho, E. C. (2014). Business incubators in Brazil: does affiliation matter? International Journal of Entrepreneurship and Small Business, 23(4), 436-455.

Chandra, A., \& Fealey, T. (2009). Business incubation in the United States, China and Brazil: A comparison of role of government, incubator funding and financial services. International Journal of Entrepreneurship, 13, 67-86.

Chandra, A., He, W., \& Fealey, T. (2007). Business Incubators in China: A financial services perspective. Asia Pacific Business Review, 13(1), 67-77.

Colombo, M. G., \& Delmastro, M. (2002). How effective are technology incubators? Evidence from Italy. Research Policy, 31, 1103-1122. doi:10.1016/S0048-7333(01)00178-0

Da Silva, A. C., Furtado, J. H., \& Zanini, R. R. (2013). Development of entrepreneurship in Brazil based on indicators of the global entrepreneurship monitor (GEM). Journal of Industrial Engineering and related areas, 15(2), 758-780. Retrieved from http://producaoonline.org.br/rpo 
Dooley, L. M. \& Lindner, J. R. (2003) The handling of nonresponse error. Human Resource Development Quarterly, 14(1), 99-110.

Elfring, T., \& Hulsink, W. (2007). Networking by entrepreneurs: Patterns of tie-formation in emerging organizations. Organization Studies, 28(12), 1849-1872. doi:10.1177/0170840607078719

Etzkowitz, H. (2002). Incubation of incubators: innovation as a triple helix of university-industry-government networks. Science and $\mathrm{Pu}-$ blic Policy, 29(2), 115-128.

Fang, S-C., Tsai, F-S, and Lin, J.L. (2010). Leveraging tenant-incubator social capital for organizational learning and performance in incubation program. International Small Business Journal, 28(1), 90-113. Gibb, A. (2000). Small and medium enterprise development: borrowing from elsewhere? A research and development agenda.

Journal of Small Business \& Enterprise Development, 7(3), 199-211. Gibb, A. (2000). Small and medium enterprise development: Borrowing from elsewhere? A research and development agenda? Journal of Small Business and Enterprise Development, 7 (3), 199-211.

Grandi, A., \& Grimaldi, R. (2004). Evolution of Incubation Models: Evidence from the Italian Incubation Industry. Industry and Higher Education, 18(1), 23-31.

Granovetter, M. S. (1973). The strength of weak ties. American Journal of Sociology, 78(6), 1360-1380.

Hackett, S. M., \& Dilts, D. M. (2004). A systematic review of business incubation research. The Journal of Technology Transfer, 29(1), 55-82.

Hansen, M. T., Chesbrough, H. W., Nohria, N., \& Sull, D. N. (2000). Networked incubators: Hothouses of the new economy. Harvard Business Review, 78(5), 74-84.

INFODEV. (2010). Global Good Practice in Incubation Policy Development and Implementation: Brazil Case Study. Retrieved from Washington, DC: http://www.infodev.org/infodev-files/resource/InfodevDocuments_835.pdf

Jaffe, A.B., Trajtenberg, M., \& Henderson, R. (1993). Geographic localization of knowledge spillovers as evidenced by patent citations. Quarterly Journal of Economics, 108 (3), 577-598.

Knopp, L. (2007). Across state lines: US incubators report how state governments support business incubation. . NBIA Review, 23(4), 6-9. Retrieved from http://www2.nbia.org/resource_library/review_archive/0807_01.php

Lalkaka, R. (2003). Business incubators in developing countries: characteristics and performance. International Journal of Entrepreneurship and Innovation Management, 3(1-2), 31-55.

Mian, S. A. (1996). Assessing value-added contributions of university technology business incubators to tenant firms. Research Policy, 25(3), 325-335. doi:10.1016/0048-7333(95)00828-4
O Neal, T. (2005). Evolving a successful university-based incubator: Lessons learned from the UCF technology incubator. Engineering Management Journal, 17(3), 11-25.

Peters, L., Rice, M., \& Sundararajan, M. (2004). The role of incubators in the entrepreneurial process. Journal of Technology Transfer, 29(1), 83-91.

Phillimore, J. (1999). Beyond the linear view of innovation in science park evaluation: An analysis of Western Australian Technology Park. Technovation, 19, 673-680. doi:10.1016/S0166-4972(99)00062-0

Ramachandran, K., \& Ray. S. (2006). Networking and new venture resource strategies: A study of information technology start-ups. Journal of Entrepreneurship, 15(2), 145-168. doi:10.1177/097135570601500203

Reed, D. P. (2001). The law of the pack. Harvard Business Review, 79(2), 23-24.

Rothaermel, F. T., \& Thursby, M. (2005). Incubator firm failure or graduation? The role of university linkages. Research Policy, 34(7), 1076-1090. doi:10.1016/j.respol.2005.05.012

Scaramuzzi, E. (2002). Incubators in developing countries: Status and development perspectives. infoDev Program, World Bank, Washington, DC. Retrieved from: http://www-wds.worldbank.org/external/default/ WDSContentServer/WDSP/IB/2003/09/03/000160016_2003090310185 3/Rendered/PDF/266370WP0Scode090incubators0Infodev.pdf

Scillitoe, J. L., \& Chakrabarti, A. K. (2010). The role of incubator interactions in assisting new ventures. Technovation, 30, 155-167. doi:10.1016/j.technovation.2009.12.002

Smilor, R. W., \& Gill, M. D. (1986). The New Business Incubator: Linking Talent, Technology, Capital And Know-How. Lexington: Lexington Books.

Soetanto, D. P., \& Jack, S. L. (2013). Business incubators and the networks of technology-based firms. Journal of Technology Transfer, 38(4), 432-453.

Special Report on Brazil. (September 28, 2013). The Economist. Retreived from http://www.economist.com/sites/default/files/20130928_brazil.pdf

Totterman, H., \& Sten, J. (2005). Start-ups: Business incubation and social capital/start-ups. International Small Business Journal, 23(5), 487-511.

Universidade de Sao Paulo. (n.d.) Cietec Incubadora de Empresas Tecnologicas. Retrieved from http://www5.usp.br/servicos/incubadora-de-empresas-tecnologicas-sao-paulo

Uzzi, B. (1997). Social structure and competition in interfirm networks: The paradox of embeddedness. Administrative Science Quarterly, 42(1), 35-67. 
Van de Ven, A. H. (1993). The development of an infrastructure for entrepreneurship. Journal of Business Venturing, 8, 222-230.

Vedovello, C., \& Godinho, M. (2003). Business incubators as a technological infrastructure for supporting small innovative firms' activities. International Journal of Entrepreneurship and Innovation Management, 3(1-2), 4-21.

von Zedtwitz, M. (2003). Classification and management of incubators: Aligning strategic objectives and competitive scope for new business facilitation. International Journal of Entrepreneurship and Innovation Management, 3(1-2), 176-196.

\section{Appendix - Incubator Services}

Physical Infrastructure

1. Receptionist Switchboard

2. Onsite Stenographic/Duplication Services

3. Onsite Computer Facilities

4. Email Facilities

5. Onsite Business Materials

6. Onsite Library-Technical Trade Publications

7. Onsite Mailroom/Shipping Services
8. FedEx/UPS or Other Overnight Shipping

9. Bus Furniture / Equipment Rental

10. Small Conference Room

11. Onsite Research Lab

Basic, Internal Consulting Services

12. Onsite Technical Consultation

13. Onsite General Business Consulting

14. Onsite Accounting Assistance

15. Onsite Financial Consultation

16. Onsite Marketing Consultation

17. Export Assistance

Specialized Services Offered by External Firm

1. Marketing Research Firm

2. Advertising Agency Referral/Access

3. Legal Firm Referral/Access

4. Venture Capital Firm 